\title{
KEBIJAKAN OFFICE CHANNELING DAN PERKEMBANGAN PERBANKAN SYARIAH SERTA PENYALURAN PEMBIAYAAN USAHA KECIL MENENGAH DI INDONESIA

\author{
(The Office Channeling Policy, the Development of Islamic Banking, and SMEs \\ Financing in Indonesia) \\ Uding Sastrawan ${ }^{1}$, M. Syamsun ${ }^{2}$, M. Najib ${ }^{3}$ \\ ${ }^{1}$ Dosen Tetap Program Keahlian Manajemen Agribisnis - Program Diploma IPB \\ 2,3 Dosen Departemen Manajemen - Fakultas Ekonomi dan Manajemen IPB
}

\author{
Diterima 9 Desember 2013/ Disetujui 16 Desember 2013
}

\begin{abstract}
This research presents Islamic banking which continuously experience growth in the banking system in Indonesia, especially after Bank Indonesia regulation (office channeling) is applied. The presence of Islamic banking is expected to strengthen the SMEs in accessing the business financing with the concept of profit and loss sharing. This research was done to find out whether the increasing development of Islamic banking give a positive response in the SMEs sector financing and other variables in line with the rising of Islamic banking portfolio. The study was based on secondary data and mostly collected from the Annual reports published by Bank Indonesia. Method of Vector Autoregression (VAR) and inferential statistics were used for data analysis. The result suggested that the development of Islamic banking was influenced by the variable of operational expenses ratio to operational revenue (BOPO), financing in SMEs sector (PYD), depositor funds (DPK), non performing financing (NPF), number of worker (PKJ), unless asset growth (GAST).
\end{abstract}

Key words: Islamic banking, Small and medium enterprises (SMEs), Vector autoregression (VAR)

\section{PENDAHULUAN}

Usaha Kecil Menengah (UKM) memiliki peran penting dan strategis bagi pertumbuhan ekonomi negara, kemampuan UKM perlu diberdayakan dan dikembangkan serta mereduksi kendala yang dialami (Sutaryo 2004). Upaya mengatasi salah satu permasalahan UKM dengan pembiayaan yang menggunakan sumber keuangan masyarakat sendiri dan menerapkan pendekatan pembangunan yang memiliki potensi keberlanjutan (sustainable). Perbankan syariah dapat menjadi harapan bagi pengembangan UKM dengan konsep bagi hasil dan membangun semangat masyarakat dari kalangan menengah kebawah dalam pengembangan UKM yang benar-benar mengembangkan potensi ekonomi.

Pemerintah dengan melakukan penyempurnaan Undang-Undang (UU) Nomor 7 tahun 1992 menjadi UU Nomor 10 Tahun 1998, secara tegas menjelaskan terdapat dua sistem perbankan (dual banking system), yaitu sistem perbankan konvensional dan sistem perbankan syariah. Pemerintah melalui Bank Indonesia dalam rangka meningkatkan peranan bank umum konvensional melaksanakan kegiatan usaha berdasarkan prinsip syariah menerbitkan Peraturan Bank Indonesia No 9/7/PBI/2007 tentang memperluas layanan (office channeling) tidak hanya untuk pendanaan tetapi juga mencakup pembiayaan. Selama periode krisis ekonomi dan moneter, Bank Umum Syariah (BUS) masih menunjukkan kinerja yang relatif lebih baik dibandingkan dengan perbankan konvensional. Hingga akhir September 1998 tercatat terdapat 55 bank bermasalah dan semuanya merupakan bank konvensional (Perwataatmaja 2002). Perkembangan perbankan syariah telah mengalami pertumbuhan yang sangat pesat dan memberikan kontribusi pada market share perbankan nasional. Namun, pertumbuhan yang pesat perbankan syariah belum memadai bila dibandingkan dengan kebutuhan masyarakat akan pelayanan perbankan syariah (Rohaya 2008).

Untuk memperkuat peran usaha UKM dalam struktur perekonomian nasional perlu peningkatan akses kredit atau pembiayaan dari perbankan kepada UKM. Usaha pemerintah dalam meningkatkan peranan perbankan tersebut dengan mengeluarkan aturan dan kebijakan seperti terbitnya UU Nomor 10 Tahun 1998 dan PBI Nomor 9/7/PBI/2007 tentang kebijakan meningkatkan peranan bank umum konvensional yang melaksanakan kegiatan usaha berdasarkan prinsip syariah. Adanya perbankan syariah dapat menjadi harapan bagi pengembangan UKM dengan konsep profit and loss sharing dan menjadi sumber pembiayaan alternatif bagi UKM. Perkembangan perbankan syariah telah mengalami pertumbuhan yang sangat pesat, baik dari sisi pertumbuhan aset maupun pertumbuhan kelembagaan atau jaringan. Namun, pertumbuhan yang pesat perbankan syariah apakah memberikan respon positif dalam penyaluran pembiayaan UKM, semakin meningkat sejalan dengan meningkatnya portofolio perbankan syariah untuk penyaluran pembiayaan di sektor UKM.

Tujuan dari penelitian ini sebagai berikut:

1) Menerangkan pengaruh variabel-variabel perkembangan perbankan syariah dalam penyaluran pembiayaan di sektor UKM

2) Menganalisis respon dinamis terhadap guncangan variabel-variabel perkembangan perbankan syariah

3) Menerangkan perkembangan perbankan syariah dengan adanya office channeling 


\section{METODOLOGI}

Penelitian dilakukan pada perbankan syariah yaitu bank umum syariah dan unit usaha syariah, dimulai bulan September sampai Oktober 2013. Jenis data yang digunakan adalah data sekunder dalam bentuk bulanan diperoleh dari statistik ekonomi dan keuangan Indonesia Bank Indonesia (SEKI-BI) dan statistik perbankan syariah Indonesia (SPS-BI). Data tersebut merupakan data time series bulanan dari tahun 2006-2012, terdapat 6 variabel yang digunakan dalam penelitian, yaitu: 1). Pembiayaan yang diberikan perbankan syariah di sektor UKM (PYD); 2). Pertumbuhan aset perbankan syariah (GAST); 3). Dana pihak ketiga perbankan syariah (DPK); 4). Non Performing Financing perbankan syariah, yaitu rasio pembiayaan bermasalah terhadap total pembiayaan (NPF); 5). Efisiensi perbankan syariah, yaitu rasio biaya operasional terhadap pendapatan operasional (BOPO); 6). Jumlah pekerja sebagai sumberdaya insani pada perbankan syariah (PKJ). Pengolahan dan analisis data dilakukan menggunakan bantuan software Microsoft office excel, software minitab 14 dan software eviews 8.

\section{Model Analisis}

\section{Metode Vector Autoregression (VAR)}

Metode Vector Autoregression (VAR) adalah suatu sistem persamaan yang memperlihatkan setiap variabel sebagai fungsi linier dari konstanta dan nilai lag dari variabel itu sendiri serta nilai lag dari variabel lain yang ada dalam sistem. VAR berordo $\mathrm{p}$ dengan $\mathrm{n}$ peubah tak bebas pada waktu ke-t dapat dimodelkan seperti pada persamaan 1 (Enders 1995).

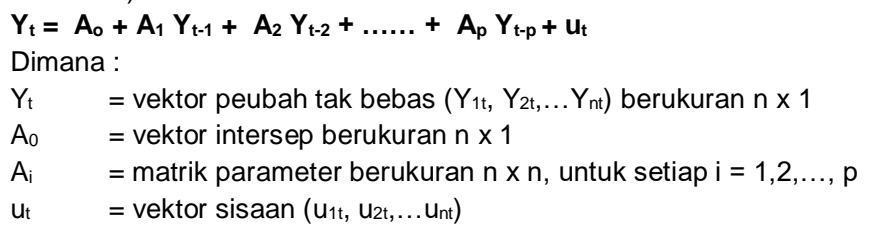

Metode analisis VAR digunakan apabila data-data yang digunakan stasioner dan tidak memiliki kointegrasi. Sedangkan apabila data-data yang digunakan tidak stasioner namun memiliki kointegrasi maka metode analisis Vector Error Correction Model (VECM) yang digunakan. Model VAR adalah bentuk autoregressif yang disebabkan oleh munculnya nilai lag dari variabel dependen dan disturbance term error pada sisi kanan persamaan. Adapun model VAR dalam bentuk matriks sebagai berikut :

$$
\left[\begin{array}{c}
P Y D_{t} \\
G A S T_{t} \\
D P K_{t} \\
N P F_{t} \\
B O P O_{t} \\
P K J_{t}
\end{array}\right]=\left[\begin{array}{l}
a_{1} \\
a_{2} \\
a_{3} \\
a_{4} \\
a_{5} \\
a_{6}
\end{array}\right]+\left[\begin{array}{l}
a_{11} a_{12} a_{13} a_{14} a_{15} a_{16} \\
a_{21} a_{22} a_{23} a_{24} a_{25} a_{26} \\
a_{31} a_{32} a_{33} a_{34} a_{35} a_{36} \\
a_{41} a_{42} a_{43} a_{44} a_{45} a_{46} \\
a_{51} a_{52} a_{53} a_{54} a_{55} a_{56} \\
a_{61} a_{62} a_{63} a_{64} a_{65} a_{66}
\end{array}\right]\left[\begin{array}{c}
P Y D_{t} \\
G A S T_{t} \\
D P K_{t} \\
N P F_{t} \\
B O P O_{t} \\
P K J_{t}
\end{array}\right]+\left[\begin{array}{c}
\varepsilon_{1 t} \\
\varepsilon_{2 t} \\
\varepsilon_{3 t} \\
\varepsilon_{4 t} \\
\varepsilon_{5 t} \\
\varepsilon_{6 t}
\end{array}\right]
$$

Keenam variabel saling mempengaruhi satu sama lain sehingga jika model VAR disajikan dalam bentuk persamaan sebagai berikut

$$
\begin{aligned}
& P Y D_{t}=a_{1}+\sum b_{1 j} P Y D_{t-j}+\sum c_{1 j} G A S T_{t-j}+\sum d_{1 j} D P K_{t-j}+\sum e_{1 j} N P F_{t-j}+\sum f_{1 j} B O P O_{t-j}+\sum g_{1 j} P K_{t-j}+\varepsilon_{1} \\
& \mathrm{GAST}_{\mathrm{t}}=\mathrm{a}_{2}+\sum \mathrm{b}_{2 \mathrm{j}} \mathrm{GAST}_{\mathrm{t}-\mathrm{j}}+\sum \mathrm{c}_{2 \mathrm{j}} \mathrm{PYD}_{\mathrm{t}-\mathrm{j}}+\sum \mathrm{d}_{2 \mathrm{j}} \mathrm{DPK}_{\mathrm{t}-\mathrm{j}}+\sum \mathrm{e}_{2 \mathrm{j}} \mathrm{NPF}_{\mathrm{t}-\mathrm{j}}+\sum \mathrm{f}_{2 \mathrm{j} j} \mathrm{BOPO}_{\mathrm{t}-\mathrm{j}}+\sum \mathrm{g}_{2 \mathrm{j}} \mathrm{PKJ}_{\mathrm{t}-\mathrm{j}}+\varepsilon_{2} \\
& \mathrm{DPK}_{\mathrm{t}}=\mathrm{a}_{3}+\sum \mathrm{b}_{3 j} \mathrm{DPK}_{\mathrm{t}-\mathrm{j}}+\sum \mathrm{c}_{3 j} \mathrm{PYD}_{\mathrm{t}-\mathrm{j}}+\sum \mathrm{d}_{3 j} \mathrm{GAST}_{\mathrm{t}-\mathrm{j}}+\sum \mathrm{e}_{3 \mathrm{j}} \mathrm{NPF}_{\mathrm{t}-\mathrm{j}}+\sum \mathrm{f}_{3 \mathrm{j}} \mathrm{BOPO}_{\mathrm{t}-\mathrm{j}}+\sum \mathrm{g}_{3 \mathrm{j}} \mathrm{PKJ}_{\mathrm{t}-\mathrm{j}}+\varepsilon_{3}
\end{aligned}
$$

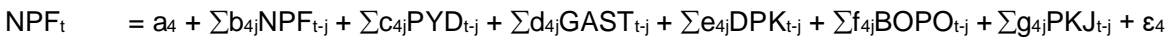

$$
\begin{aligned}
& \mathrm{BOPO}_{\mathrm{t}}=\mathrm{a}_{5}+\sum \mathrm{b}_{5 j} \mathrm{BOPO}_{\mathrm{t}-\mathrm{j}}+\sum \mathrm{C}_{5 j} \mathrm{PYD}_{\mathrm{t}-\mathrm{j}}+\sum \mathrm{d}_{5 j} \mathrm{GAST}_{\mathrm{t}-\mathrm{j}}+\sum \mathrm{e}_{5 j} \mathrm{DPK}_{\mathrm{t}-\mathrm{j}}+\sum \mathrm{f}_{5 j} \mathrm{NPF}_{\mathrm{t}-\mathrm{j}}+\sum \mathrm{g}_{5 j \mathrm{j}} \mathrm{PKJ}_{\mathrm{t}-\mathrm{j}}+\varepsilon_{5} \\
& P K_{t}=a_{6}+\sum b_{6 j} P J_{t-j}+\sum c_{6 j} P Y D_{t-j}+\sum d_{6 j} G A S T_{t-j}+\sum e_{6 j} D P K_{t-j}+\sum f_{6 j} N P F_{t-j}+\sum g_{6 j} B O P O_{t-j}+\varepsilon_{6}
\end{aligned}
$$

Berikut beberapa pengujian dalam analisis:

1. Pengujian stasioner

Pengukuran stasioneritas data menggunakan The Augmented Dickey Fuller (ADF) test. Jika nilai ADF statistic < MacKinnon critical value maka data tersebut stasioner. Namun jika nilai ADF statistic > MacKinnon critical value maka data tersebut tidak stasioner. Apabila uji ADF telah dilakukan pada data time series dan diketahui bahwa hasilnya adalah tidak stasioner maka dilakukan difference non stationary processes (Enders 1995).

2. Penentuan Lag Optimal

Penentuan lag yang optimal dapat menggunakan kriteria informasi Schwarz Information Criteria (SC), untuk menetapkan tingkat lag yang paling optimal, model VAR atau VECM harus diestimasi dengan tingkat lag yang berbeda-beda. Nilai SC yang paling kecil dipakai sebagai patokan pada tingkat lag paling optimal, karena menggambarkan residual (error) yang paling kecil (Enders 1995).

3. Pengujian Kointegrasi

Uding Sastrawan, M. Syamsun, M. Najib 
Kointegrasi dapat diinterpretasikan sebagai hubungan jangka panjang antar variabel yang telah memenuhi persyaratan selama proses integrasi yaitu dimana semua variabel telah stasioner pada derajat yang sama yaitu derajat 1. Uji kointegrasi menggunakan uji kointegrasi Johansen dengan hipotesis sebagai berikut:

$\mathrm{H}_{0}=$ tidak terkointegrasi

$$
\mathrm{H}_{1}=\text { kointegrasi }
$$

Jika trace statistic > critical value, maka tolak $\mathrm{H}_{0}$ atau terima $\mathrm{H}_{1}$ yang artinya terjadi kointegrasi. Analisis Vector Error Correction Model (VECM) dapat dilanjutkan setelah jumlah persamaan yang terkointegrasi diketahui.

4. Uji dan Analisis Granger Causality (Kausalitas Granger)

Untuk mengukur kekuatan hubungan antar variabel dan menunjukkan arah hubungan sebab akibat, dimana $X$ menyebabkan $\mathrm{Y}, \mathrm{Y}$ menyebabkan $\mathrm{X}$, atau $\mathrm{X}$ menyebabkan $\mathrm{Y}$ dan $\mathrm{Y}$ menyebabkan $\mathrm{X}$. Uji kausalitas Granger dipercaya jauh lebih bermakna dari uji korelasi biasa (Ascarya 2009).

Data akan diolah dan dianalisis sesuai dengan metode analisis yang digunakan, berikut bagan alir dari proses analisis dan uji statistik disajikan pada Gambar 1.

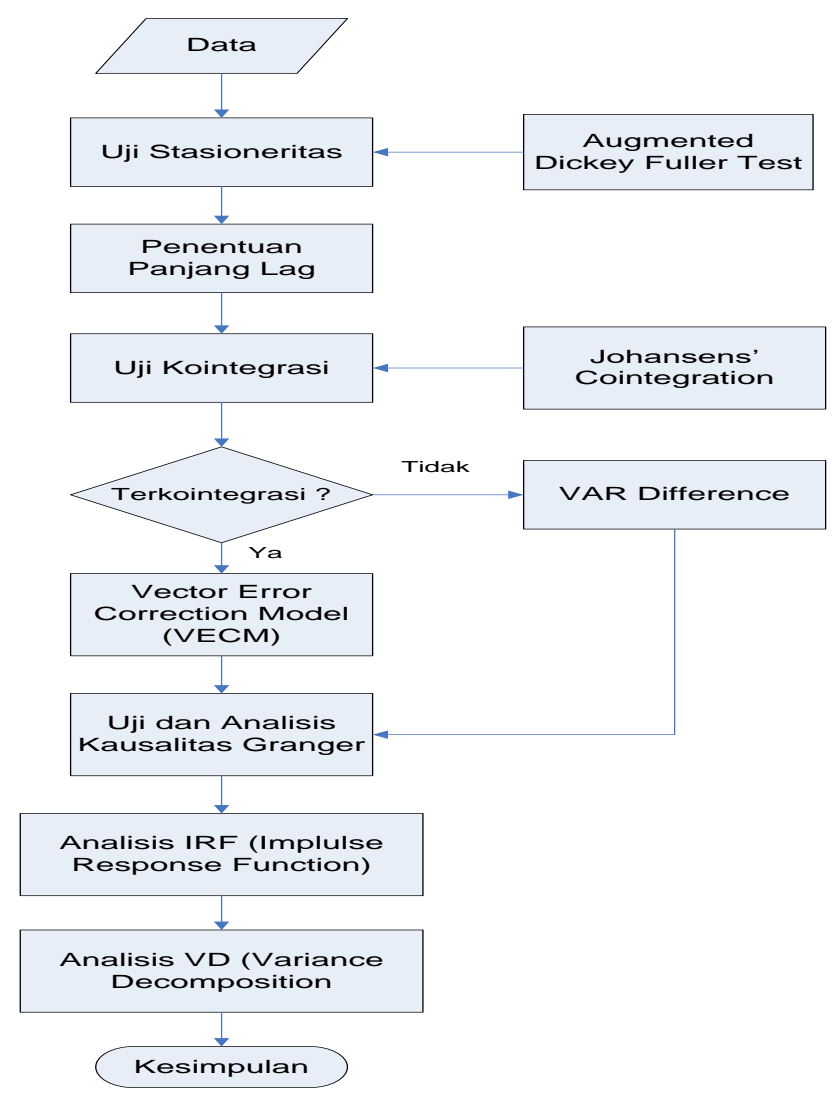

Gambar 1 Bagan alir dari proses analisis dan uji statistik

\section{Statistik Inferensia}

Secara umum hipotesis penelitian adalah:

$\mathrm{H}_{0}$ : tidak ada perbedaan yang nyata antara perkembangan perbankan syariah sebelum dan setelah office channeling $\left(\mathrm{H}_{0}: \mu 1=\mu 2\right)$

$\mathrm{H}_{1}$ : terdapat perbedaan yang nyata antara perkembangan perbankan syariah sebelum dan setelah office channeling $\left(\mathrm{H}_{1}: \mu 1 \neq \mu 2\right)$

Pengujian statistik yang digunakan untuk sampel kecil adalah statistik-t (Newbold et al. 2007). Kriteria penerimaan hipotesis: Jika $t_{\text {stat }}>t_{\text {tabel }}$ maka tolak $\mathrm{H}_{0}$, sebaliknya jika $t_{\text {stat }}<t_{\text {tabel }}$ maka terima $\mathrm{H}_{0}$. 


\section{HASIL DAN PEMBAHASAN}

\section{Hasil Analisis Data}

Uji Stasioneritas Data

Untuk memastikan kestasioneran data dilakukan uji Augmented Dickey Fuller Test pada taraf nyata 5\%. Jika nilai t-ADF lebih kecil dari nilai kritis MacKinnon, maka data yang digunakan adalah stasioner (tidak mengandung akar unit) dan sebaliknya.

Tabel 1 Hasil uji stasioneritas data

\begin{tabular}{lcccc}
\hline & \multirow{2}{*}{ Variabel } & \multicolumn{2}{c}{ Nilai ADF } & \multicolumn{2}{c}{ Nilai Kritis MacKinnon 5\% } \\
\cline { 2 - 5 } & \multicolumn{10}{c}{ Level } & $1^{\text {st }}$ Difference & Level & $1^{\text {st }}$ Difference \\
\hline GAST & $-\mathbf{1 0 0 0 1 2}$ & $\mathbf{- 1 4 . 7 4 3 0 1}$ & -2.896779 & -2.897678 \\
NPF & -1.484142 & $\mathbf{- 1 2 . 7 2 4 1 6}$ & -2.897223 & -2.897223 \\
PYD & -0.601827 & $\mathbf{- 8 . 6 2 3 0 8 9}$ & -2.896779 & -2.897223 \\
DPK & 0.778581 & $\mathbf{- 1 1 . 2 9 4 5 6}$ & -2.896779 & -2.897223 \\
BOPO & $\mathbf{- 3 . 2 1 4 2 4 9}$ & $\mathbf{- 1 2 . 6 7 3 4 4}$ & -2.896779 & -2.897223 \\
PKJ & -0.593668 & $\mathbf{- 9 . 4 7 7 6 8 9}$ & -2.896779 & -2.897223 \\
\hline
\end{tabular}

Ket: Cetak tebal menunjukkan data stasioner pada taraf $5 \%$

Hasil uji stasioneritas data (Tabel 1) menunjukkan variabel dalam penelitian tidak seluruhnya stasioner pada tingkat level hanya variabel GAST dan BOPO memilik data stasioner. Oleh karena itu pengujian dilanjutkan pada tingkat first difference, hasilnya semua variabel datanya stasioner pada taraf nyata $5 \%$. Artinya semua data yang digunakan pada penelitian terintegrasi pada ordo 1 atau disingkat menjadi I (1). Hal ini menunjukkan semua data deret waktu setelah dilakukan pembedaan dan model yang dipilih adalah vector error correction model (VECM).

\section{Penentuan Lag Optimal}

Penentuan tingkat lag optimal menggunakan nilai Schwarz Information Criteria (SC) yang terkecil. Nilai SC untuk setiap lag-nya (Tabel 2) diperoleh nilai minimum pada lag 1, sehingga penentuan lag optimal adalah lag 1. Selanjutnya uji kointegrasi, estimasi VECM dan variance decomposition akan dilakukan pada lag optimal.

Tabel 2 Hasil uji lag optimal

\begin{tabular}{ccccccc}
\hline Lag & LogL & LR & FPE & AIC & SC & HQ \\
\hline 1 & 53.69480 & NA & $2.55 \mathrm{e}-08^{*}$ & $-0.459605^{*}$ & $0.636200^{*}$ & $-0.021293^{*}$ \\
2 & 87.18946 & 56.54943 & $2.76 \mathrm{e}-08$ & -0.394532 & 1.797079 & 0.482093 \\
3 & 119.0468 & 48.82035 & $3.19 \mathrm{e}-08$ & -0.286930 & 3.000485 & 1.028007 \\
4 & 135.6605 & 22.87083 & $5.69 \mathrm{e}-08$ & 0.216610 & 4.599830 & 1.969859 \\
5 & 171.6866 & 43.97988 & $6.49 \mathrm{e}-08$ & 0.215932 & 5.694958 & 2.407495 \\
6 & 201.1535 & 31.38029 & $9.50 \mathrm{e}-08$ & 0.385624 & 6.960455 & 3.015499 \\
7 & 259.7591 & $53.27786^{*}$ & $7.31 \mathrm{e}-08$ & -0.201535 & 7.469101 & 2.866652 \\
\hline
\end{tabular}

Tanda asterik (*) mengindikasikan Lag terpilih oleh kriteria

\section{Uji Kointegrasi}

Uji Kointegrasi Johansen dengan kriteria pengujian kointegrasi berdasarkan pada trace-statistics, jika nilai trace-statistics < nilai critical value maka variabel tersebut tidak terkointegrasi. Sebaliknya jika nilai trace-statistics > nilai critical value maka variabel tersebut terkointegrasi. Hasil pengujian kointegrasi (Tabel 3) menunjukkan terdapat 6 persamaan terkointegrasi pada taraf nyata $5 \%$. Hal ini menunjukkan bahwa masing-masing variabel saling mempengaruhi dan memiliki hubungan stabilitas atau keseimbangan dan kesamaan pergerakan dalam jangka panjang.

Tabel 3 Hasil uji kointegrasi

\begin{tabular}{|c|c|c|c|c|}
\hline Hypothesized & & Trace & 0.05 & \\
\hline No. of $C E(s)$ & Eigenvalue & Statistic & Critical Value & Prob. ** \\
\hline None * & 0.539163 & 190.3909 & 95.75366 & 0.0000 \\
\hline At most 1 * & 0.451505 & 126.8646 & 69.81889 & 0.0000 \\
\hline At most 2 * & 0.342433 & 77.61724 & 47.85613 & 0.0000 \\
\hline At most 3 * & 0.235827 & 43.24207 & 29.79707 & 0.0008 \\
\hline At most 4 * & 0.182167 & 21.18730 & 15.49471 & 0.0062 \\
\hline At most 5 * & 0.055674 & 4.697302 & 3.841466 & 0.0302 \\
\hline
\end{tabular}

Trace test indicates 6 cointegrating eqn(s) at the 0.05 level

* denotes rejection of the hypothesis at the 0.05 level

${ }^{* *}$ MacKinnon-Haug-Michelis (1999) p-values 


\section{Estimasi Vector Error Correction Model}

Hasil estimasi VECM diperoleh persamaan jangka panjang dan jangka pendek untuk setiap variabel perkembangan perbankan syariah (Tabel 4 dan 5). Persamaan BOPO sebagai variabel endogen dalam jangka panjang dipengaruh negatif dan signifikan pada taraf nyata 5\% oleh variabel PYD. Apabila terjadi peningkatan PYD sebesar 1\% pada 1 periode sebelumnya maka akan menurunkan BOPO sebesar $0.862424 \%$, sedangkan dalam jangka pendek, semua variabel eksogennya tidak berpengaruh signifikan terhadap BOPO. Hubungan variabel BOPO terhadap BOPO sendiri, GAST, PKJ dan PYD bersifat negatif, namun terhadap variabel DPK dan NPF bersifat positif.

Tabel 4 Hasil estimasi VECM persamaan BOPO, DPK dan GAST

\begin{tabular}{ccccccc}
\hline \multirow{2}{*}{ Variabel } & \multicolumn{2}{c}{ BOPO } & \multicolumn{2}{c}{ DPK } & \multicolumn{2}{c}{ GAST } \\
\cline { 2 - 6 } & Koefisien & T-Statistik & Koefisien & T-Statistik & Koefisien & T-Statistik \\
\hline Jangka Pendek & & & & & & \\
CointEq1 & -0.277823 & $-2.68402^{*}$ & -0.046679 & $-3.27622^{*}$ & -0.122890 & -0.70482 \\
CointEq2 & -1.749318 & -1.40532 & -0.424959 & $-2.48020^{*}$ & -2.621438 & -1.25023 \\
CointEq3 & 0.084831 & 0.69688 & -0.011460 & -0.68394 & -1.322631 & $-6.45035^{*}$ \\
CointEq4 & 0.057811 & 0.61944 & -0.033141 & $-2.57981^{*}$ & 0.044704 & 0.28437 \\
CointEq5 & 1.563676 & 1.22895 & 0.373170 & $2.13073^{*}$ & 5.005484 & $2.33549^{*}$ \\
D(BOPO(-1)) & -0.162402 & -1.26635 & 0.028794 & 1.63117 & 0.143693 & 0.66519 \\
D(DPK(-1)) & 0.699990 & 1.12588 & 0.053946 & 0.63036 & 1.342200 & 1.28162 \\
D(GAST(-1)) & -0.018299 & -0.24950 & 0.008521 & 0.84404 & 0.063892 & 0.51717 \\
D(NPF(-1)) & 0.001507 & 0.01168 & 0.015646 & 0.88094 & -0.307322 & -1.41395 \\
D(PKJ(-1)) & -1.267573 & -1.43925 & 0.055689 & 0.45938 & -2.562474 & -1.72729 \\
D(PYD(-1)) & -0.472502 & -0.65910 & 0.110702 & 1.12185 & 0.213586 & 0.17687 \\
C & 0.091225 & 1.07124 & 0.050686 & $4.32411^{*}$ & 0.099527 & 0.69384 \\
Jangka Panjang & & & & & & \\
PYD(-1) & -0.862424 & $-5.52261^{*}$ & -0.998116 & $-66.5937^{*}$ & -0.079672 & -1.00047 \\
C & -0.519230 & & 0.001971 & & -3.316431 & \\
\hline
\end{tabular}

Tanda asterik $\left(^{*}\right)$ mengindikasikan variabel signifikan pada taraf nyata $5 \%$

Persamaan DPK sebagai variabel endogen dalam jangka panjang, dipengaruh negatif dan signifikan variabel PYD sedangkan pada persamaan GAST sebagai variabel endogen variabel PYD berpengaruh negatif, namun tidak signifikan pada taraf nyata 5\%. Jika terdapat peningkatan PYD sebesar $1 \%$ pada 1 periode sebelumnya maka akan menurunkan DPK sebesar $0.998116 \%$. Sedangkan persamaan DPK jangka pendek, semua variabel eksogennya tidak berpengaruh signifikan, hubungan variabel DPK terhadap semua variabel eksogennya bersifat positif. Sama halnya pada persamaan GAST jangka pendek, semua variabel eksogennya tidak berpengaruh signifikan. Namun hubungan variabel GAST dengan GAST sendiri, BOPO, DPK dan PYD bersifat positif, sedangkan variabel PKJ dan NPF bersifat negatif.

Tabel 5 Hasil estimasi VECM persamaan NPF, PKJ dan PYD

\begin{tabular}{ccccccc}
\hline \multirow{2}{*}{ Variabel } & \multicolumn{2}{c}{ NPF } & \multicolumn{2}{c}{ PKJ } & \multicolumn{2}{c}{ PYD } \\
\cline { 2 - 6 } & Koefisien & T-Statistik & Koefisien & T-Statistik & Koefisien & T-Statistik \\
\hline Jangka Pendek & & & & & & \\
CointEq1 & 0.165559 & 1.77426 & -0.052466 & $-2.92654^{*}$ & -0.037314 & $-2.03320^{*}$ \\
CointEq2 & 2.626798 & $2.34089^{*}$ & 0.636010 & $2.95006^{*}$ & 0.393279 & 1.78194 \\
CointEq3 & -0.052201 & -0.47570 & -0.026532 & -1.25846 & -0.037260 & -1.72635 \\
CointEq4 & -0.243558 & $-2.89493^{*}$ & -0.022833 & -1.41257 & -0.029918 & -1.80801 \\
CointEq5 & -3.000420 & $-2.61588^{*}$ & -0.736721 & $-3.34311^{*}$ & 0.338872 & 1.50214 \\
D(BOPO(-1)) & -0.098787 & -0.85450 & 0.071911 & $3.23755^{*}$ & 0.004949 & 0.21765 \\
D(DPK(-1)) & -0.833973 & -1.48799 & -0.071450 & -0.66353 & -0.060599 & -0.54973 \\
D(GAST(-1)) & 0.045640 & 0.69029 & 0.010727 & 0.84445 & 0.024348 & 1.87237 \\
D(NPF(-1)) & -0.233303 & $-2.00570^{*}$ & 0.036922 & 1.65213 & 0.025307 & 1.10616 \\
D(PKJ(-1)) & 2.596806 & $3.27078^{*}$ & 0.168072 & 1.10184 & 0.090882 & 0.58201 \\
D(PYD(-1)) & -0.560946 & -0.86799 & 0.176824 & 1.42412 & 0.213704 & 1.68130 \\
C & -0.099977 & -1.30233 & 0.039675 & $2.69000^{*}$ & 0.042555 & $2.81846^{*}$ \\
Jangka Panjang & & & & & & \\
PYD(-1) & 0.788309 & $4.48068^{*}$ & -0.992499 & $-71.2413^{*}$ & & \\
C & -6.482024 & & -0.027043 & & &
\end{tabular}

Tanda asterik $\left(^{*}\right)$ mengindikasikan variabel signifikan pada taraf nyata $5 \%$

Persamaan NPF dan PKJ sebagai variabel endogen dalam jangka panjang pada taraf nyata $5 \%$ dipengaruhi secara signifikan oleh variabel PYD. Hubungan variabel PYD dengan NPF berpengaruh positif, sedangkan dengan PKJ berpengaruh negatif. Apabila terjadi peningkatan PYD sebesar $1 \%$ pada 1 periode sebelumnya maka akan meningkatkan NPF sebesar $0.788309 \%$ dan akan menurunkan PKJ sebesar $0.992499 \%$. Sedangkan dalam jangka pendek persamaan NPF dipengaruhi signifikan oleh variabel NPF itu sendiri sebesar -0.233303 dan PKJ sebesar Uding Sastrawan, M. Syamsun, M. Najib 
2.596806 pada 1 periode sebelumnya dengan hubungan variabel NPF negatif dan PKJ positif. Namun, untuk variabel eksogen lainnya tidak berpengaruh signifikan terhadap NPF. Hasil etimasi VECM persamaan PKJ jangka pendek dipengaruhi positif oleh variabel BOPO sebesar 0.071911 pada 1 periode sebelumnya dan signifikan pada taraf nyata 5\%. Namun, untuk variabel eksogen lainnya tidak berpengaruh signifikan terhadap PKJ. Hubungan variabel PKJ itu sendiri, BOPO, GAST, NPF dan PYD bersifat positif, sedangkan variabel DPK bersifat negatif. Pada persamaan PYD sebagai variabel endogen dalam jangka pendek semua variabel eksogen pada 1 periode sebelumnya tidak berpengaruh signifikan. Hubungan variabel PYD dengan PYD sendiri, BOPO, GAST, NPF dan PKJ bersifat positif, sedangkan variabel DPK bersifat negatif.

\section{Uji Kausalitas Granger}

Hasil uji kausalitas Granger (Gambar 2) menunjukkan variabel dengn hubungan dua arah adalah PKJ dengan DPK, PYD dengan DPK, PKJ dengan NPF, PYD dengan NPF dan PKJ dengan PYD. Variabel dengan hubungan satu arah adalah DPK dengan BOPO, PKJ dengan BOPO, PYD dengan BOPO, DPK dengan NPF dan PKJ dengan GAST. Sedangkan variabel yang tidak terjadi hubungan diantaranya adalah BOPO dengan GAST, BOPO dengan NPF, DPK dengan GAST, GAST dengan NPF dan GAST dengan PYD.

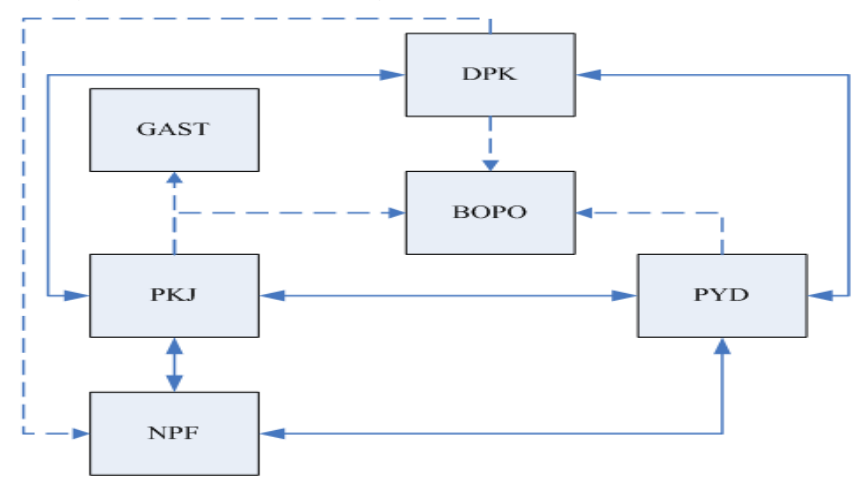

Keterangan;

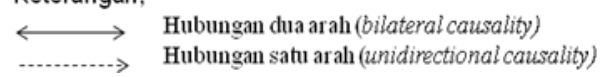

Gambar 2 Hubungan antar variabel perkembangan perbankan syariah

\section{Analisis Impuls Respon Function (IRF)}

Untuk mengetahui pengaruh suatu standar deviasi diguncang terhadap perubahan yang terjadi pada nilai variabel endogen pada saat ini dan dimasa yang akan datang. Analisis IRF ditunjukan dalam bentuk grafik (Gambar 3), dimana sumbu $\mathrm{x}$ (horizontal) merupakan periode setelah terjadinya guncangan, sedangkan sumbu y (vertikal) merupakan nilai respon, analisis ini digunakan untuk mengetahui respon positif atau negatif dari suatu variabel terhadap variabel lainnya.

\section{Forecast Error Variance Decomposition (FEVD)}

Variance decomposition memberikan informasi tentang kepentingan relatif dari setiap inovasi acak dalam mempengaruhi variabel dalam VAR. Struktur dinamis antar variabel dalam VAR dapat dilihat melalui analisis Forecasting Error Variance Decomposition (FEVD). Pengurutan variabel dalam analisi FEVD ini didasarkan pada faktorisasi Cholesky, hasil dekomposisi varian variabel perkembangan perbankan syariah disajikan pada Tabel 6 . Pada periode pertama fluktuasi variabel BOPO dipengaruhi guncangan BOPO itu sendiri sebesar $100 \%$, sedangkan pengaruh variabel lain belum terlihat. Pada interval peramalan periode selanjutnya, pengaruh guncangan BOPO itu sendiri semakin menurun tetapi masih dominan. Keadaan serupa juga terjadi pada variabel DPK, GAST dan NPF. Pada periode pertama fluktuasi DPK dipengaruhi guncangan DPK itu sendiri (99.03\%) dan BOPO (0.96\%). Fluktuasi GAST dipengaruhi guncangan GAST itu sendiri (80.44\%), BOPO (0.15\%) dan DPK (19.40\%). Sedangkan fluktuasi NPF dipengaruhi guncangan NPF itu sendiri $(75.70 \%)$, BOPO (4.30\%), DPK (1.83\%) dan GAST (18.16\%). Untuk pengaruh variabel lainnya belum terlihat. Sampai periode ke-12, fluktuasi BOPO, DPK, GAST dan NPF masih dominan dipengaruhi oleh guncangan variabel dirinya sendiri daripada variabel lainnya. 

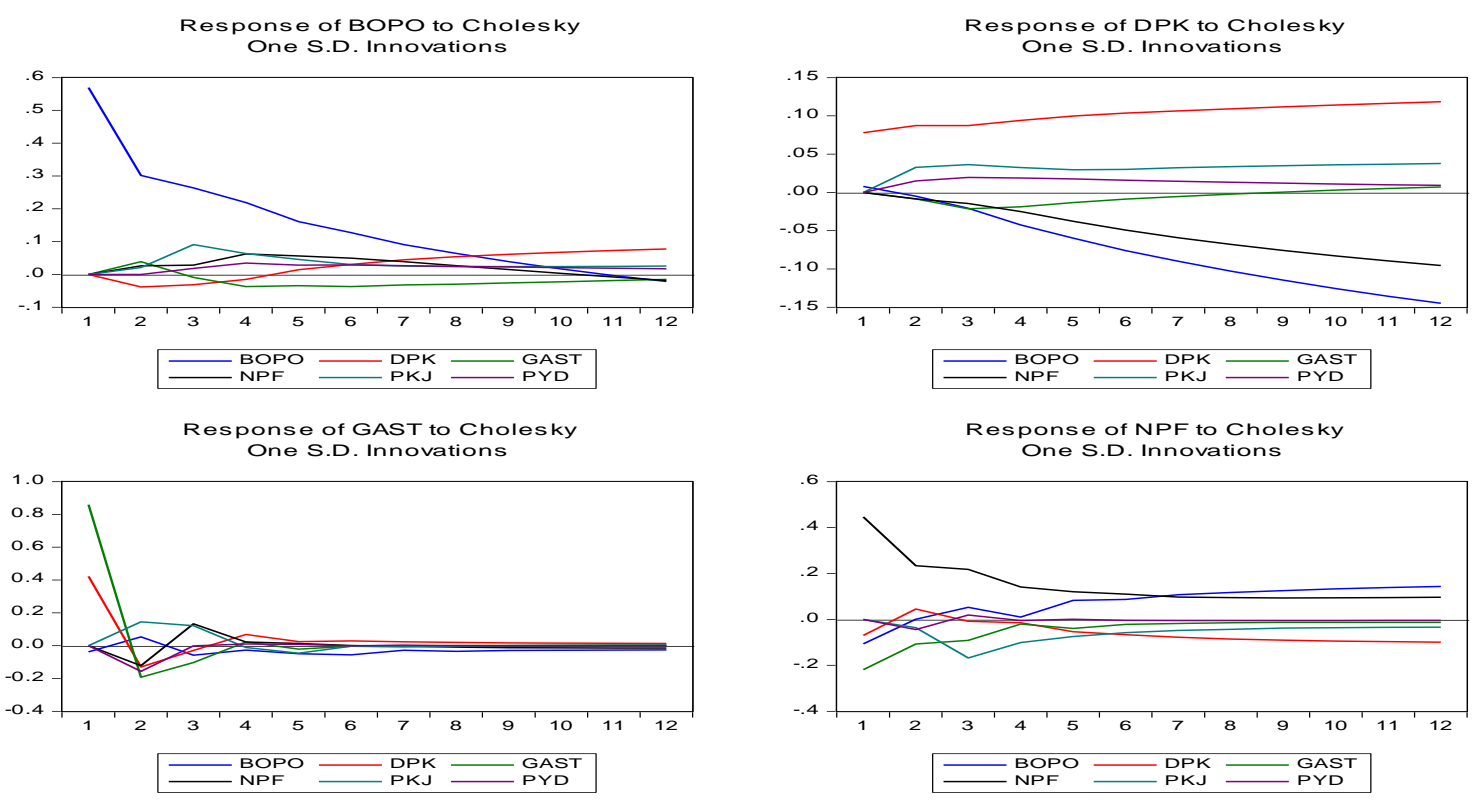

Response of PKJ to Cholesky One S.D. Innovations
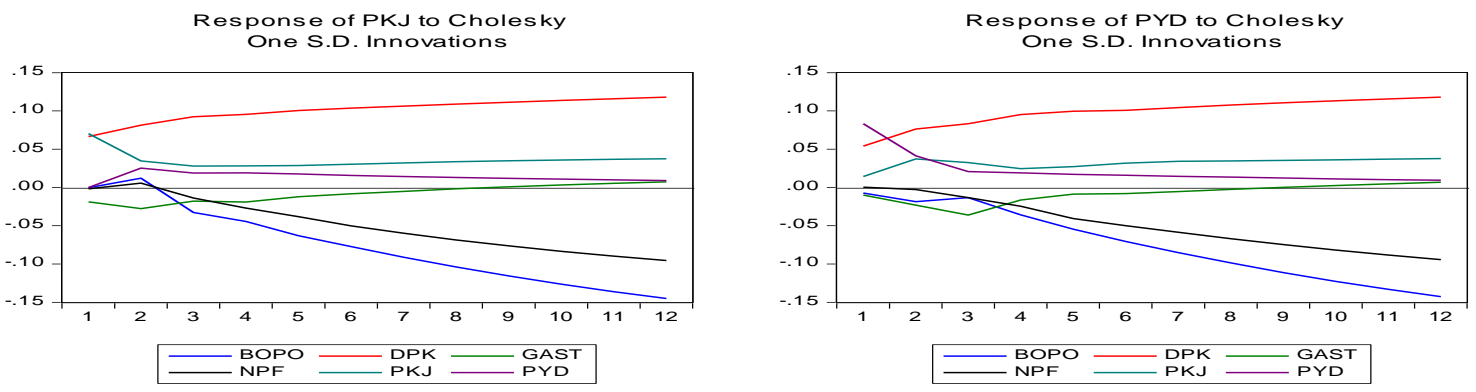

Gambar 3. Respon variabel perkembangan perbankan syariah terhadap guncangan variabel lainnya

Berbeda kondisi dengan variabel PKJ dan PYD, pada periode pertama fluktuasi variabel PKJ dipengaruhi guncangan PKJ itu sendiri (50.76\%), BOPO (0.001\%), DPK (45.58\%), GAST (3.61\%) dan NPF (0.031\%), sedangkan pengaruh variabel PYD belum terlihat. Untuk fluktuasi variabel PYD dipengaruhi guncangan PYD itu sendiri $(67.88 \%)$, BOPO (0.52\%), DPK (28.64\%), GAST (0.96\%) dan NPF (0.001\%). Setelah periode pertama sampai ke-12, fluktuasi PKJ dan PYD dominan dipengaruhi guncangan variabel DPK dan BOPO dalam menjelaskan variabilitas, hal ini menunjukkan bahwa fluktuasi variabel PKJ dan PYD lebih banyak dipengaruhi oleh variabel DPK dan BOPO daripada variabel PKJ dan PYD itu sendiri. 
Tabel 6 Dekomposisi varian untuk variabel BOPO, DPK, GAST, NPF, PKJ dan PYD

\begin{tabular}{cccccccc}
\hline $\begin{array}{c}\text { Variabel } \\
\text { endogen }\end{array}$ & \multirow{2}{*}{ Periode } & \multicolumn{5}{c}{ Dijelaskan oleh guncangan } \\
\cline { 2 - 7 } BOPO & 1 & BOPO & DPK & GAST & NPF & PKJ & PYD \\
& 4 & $\mathbf{1 0 0 . 0 0 0}$ & 0.000 & 0.000 & 0.000 & 0.000 & 0.000 \\
& 8 & $\mathbf{9 5 . 4 7 6}$ & 0.481 & 0.533 & 0.956 & 2.284 & 0.268 \\
& 12 & $\mathbf{9 2 . 0 4 4}$ & 1.364 & 1.167 & 2.070 & 2.660 & 0.692 \\
\hline DPK & $\mathbf{8 8 . 4 7 1}$ & 4.261 & 1.382 & 2.0798 & 2.902 & 0.902 \\
\hline & 4 & 0.961 & $\mathbf{9 9 . 0 3 8}$ & 0.000 & 0.000 & 0.000 & 0.000 \\
& 8 & 5.971 & $\mathbf{7 7 . 9 8 4}$ & 2.281 & 2.352 & 8.926 & 2.484 \\
& 12 & 34.736 & $\mathbf{5 7 . 9 9 3}$ & 0.914 & 10.067 & 5.789 & 1.498 \\
GAST & 1 & 0.158 & 19.400 & $\mathbf{8 0 . 4 4 1}$ & 0.000 & 0.000 & 0.000 \\
& 4 & 0.764 & 18.423 & $\mathbf{7 2 . 2 0 9}$ & 3.032 & 3.293 & 2.276 \\
& 8 & 1.441 & 18.421 & $\mathbf{7 1 . 4 1 0}$ & 3.020 & 3.450 & 2.255 \\
& 12 & 1.703 & 18.424 & $\mathbf{7 1 . 1 1 0}$ & 3.078 & 3.437 & 2.245 \\
\hline NPF & 1 & 4.300 & 1.830 & 18.165 & $\mathbf{7 5 . 7 0 3}$ & 0.000 & 0.000 \\
& 4 & 3.136 & 1.573 & 15.017 & $\mathbf{7 0 . 9 8 3}$ & 8.766 & 0.523 \\
& 8 & 9.388 & 4.848 & 12.295 & $\mathbf{6 3 . 8 6 5}$ & 9.177 & 0.423 \\
& 12 & 17.545 & 8.857 & 9.821 & $\mathbf{5 5 . 4 6 6}$ & 7.960 & 0.347 \\
\hline PKJ & 1 & $\mathbf{0 . 0 0 1}$ & $\mathbf{4 5 . 5 8 3}$ & 3.614 & 0.031 & 50.769 & 0.000 \\
& 4 & $\mathbf{7 . 3 1 0}$ & $\mathbf{6 5 . 6 8 7}$ & 4.123 & 2.164 & 17.618 & 3.095 \\
& 8 & $\mathbf{2 4 . 0 6 2}$ & $\mathbf{5 4 . 2 2 5}$ & 1.528 & 9.848 & 8.636 & 1.698 \\
& 12 & $\mathbf{3 4 . 7 0 1}$ & $\mathbf{4 3 . 0 3 3}$ & 0.735 & 14.821 & 5.777 & 0.930 \\
\hline PYD & 1 & $\mathbf{0 . 5 2 6}$ & $\mathbf{2 8 . 6 4 9}$ & 0.967 & 0.001 & 1.969 & 67.886 \\
& 4 & $\mathbf{4 . 3 9 5}$ & $\mathbf{5 8 . 5 5 8}$ & 5.220 & 1.853 & 7.681 & 22.289 \\
& 8 & $\mathbf{2 1 . 0 8 0}$ & $\mathbf{5 2 . 9 6 9}$ & 1.876 & 10.115 & 5.799 & 8.158 \\
& 12 & $\mathbf{3 2 . 9 9 4}$ & $\mathbf{4 2 . 7 7 1}$ & 0.878 & 14.941 & 4.542 & 3.871 \\
\hline
\end{tabular}

\section{Uji Beda Variabel Pengaruh Perkembangan Perbankan Syariah}

Hasil uji beda variabel perkembangan perbankan syariah (Tabel 7) menunjukkan hipotesis yang menyatakan terdapat perbedaan yang nyata variabel perkembangan perbankan syariah sebelum dan sesudah office channeling diterima pada taraf nyata $5 \%$ adalah BOPO, DPK, NPF PKJ dan PYD. Sedangkan variabel GAST secara statistik tidak berbeda nyata dengan nol (terima $\mathrm{H}_{0}$ ). Adanya office channeling memberikan berpengaruh signifikan terhadap peningkatan pembiayaan syariah yang diberikan di sektor UKM, semakin meningkat perkembangan perbankan syariah memberi dampak pada peningkatan penyaluran pembiayaan di sektor UKM. Artinya adanya peraturan perundangudangan dan kebijakan Bank Indonesia terkait perbankan syariah memberi pengaruh pada perkembangan perbankan syariah di Indonesia dewasa ini. 
Tabel 7 Hasil uji beda variabel perkembangan perbankan syariah

\begin{tabular}{cllllllll}
\hline \multirow{2}{*}{$\begin{array}{c}\text { Jumlah } \\
\text { observasi }\end{array}$} & \multicolumn{2}{c}{ Sebelum office channeling } & \multicolumn{2}{c}{ Sesudah office channeling } & \multirow{2}{*}{$T$-value } & \multirow{2}{*}{$P$-value } \\
\cline { 2 - 6 } & Variabel & Mean & Std dev & Variabel & Mean & Std dev & \\
\hline 24 & BOPO & 2.461 & 0.566 & BOPO & 3.690 & 0.802 & $-6.13^{*}$ & 0.000 \\
24 & DPK & 2.417 & 0.516 & DPK & 3.420 & 0.220 & $-8.76^{*}$ & 0.000 \\
24 & GAST & 3.428 & 0.914 & GAST & 3.515 & 0.858 & -0.34 & 0.736 \\
24 & NPF & 4.439 & 0.852 & NPF & 3.889 & 0.767 & $2.35^{*}$ & 0.023 \\
24 & PKJ & 2.420 & 0.517 & PKJ & 3.434 & 0.261 & $-8.58^{*}$ & 0.000 \\
24 & PYD & 2.422 & 0.521 & PYD & 3.415 & 0.229 & $-8.55^{*}$ & 0.000 \\
\hline
\end{tabular}

Tanda asterik $\left({ }^{*}\right)$ menunjukkan variabel signifikan pada taraf nyata $5 \%$

\section{Implikasi Manajerial}

Implikasi manajerial yang dapat dilakukan, rasio biaya operasional terhadap pendapatan operasional (BOPO) perbankan syariah merupakan indikator efisiensi usaha perbankan, upaya peningkatan pembiayaan yang diberikan di sektor UKM (PYD) dapat menurunkan rasio BOPO pada periode berikutnya. Dana pihak ketiga (DPK) merupakan dana dari deposan berupa tabungan, giro dan deposito, semakin besar nilai DPK menandakan bank semakin dipercaya oleh nasabah sehingga dapat meningkatkan kapasitas penyaluran pembiayaan. Penyaluran pembiayaan semakin besar menandakan masyarakat semakin percaya dan mudah mengakses permodalan pada perbankan syariah sehingga dapat mendorong nilai DPK. Upaya meningkatkan kepercayaan nasabah terhadap perbankan syariah sangat penting dilakukan dapat melalui fungsi penghimpun dana (funding) dan penyalur dana (lending).

Rasio pembiayaan bermasalah (macet) terhadap total pembiayaan (NPF) merupakan risiko keuangan perbankan syariah karena menunjukkan kemampuan kolektibilitas bank dalam mengumpulkan kembali pembiayaan yang disalurkan. Peningkatan pembiayaan yang diberikan di sektor UKM (PYD) berpengaruh pada nilai NPF naik pada periode berikutnya. Atau adanya peningkatan nilai NPF dipengaruh pembiayaan yang diberikan di sektor UKM (PYD) naik pada periode sebelumnya. Untuk menurunkan risiko keuangan perbankan syariah dengan memperkecil nilai NPF melalui penurunkan jumlah pembiayaan bermasalah (macet) atau jumlah pembiayaan yang diberikan pada periode sebelumnya. Langkah menurunkan risiko keuangan dapat tercapai diperlukan pengawasan sistem pembiayaan dan selektif dalam penerapan kebijakan pembiayaan yang ekspansif. Jumlah pekerja (PKJ) merupakan sumberdaya insani yang menjalankan kegiatan operasional, keberhasilan suatu institusi bisnis tergantung pada sumberdaya insani yang tersedia. Dalam kondisi jangka panjang, untuk menunjang keberhasilan kegiatan operasional perbankan syariah dalam penyaluran pembiayaan perlu meningkatkan sumberdaya insani, sehingga akan mempercepat proses pelayanan pembiayaan yang diberikan di sektor UKM pada periode berikutnya.

Melalui analisis Impuls Respon Function (IRF) memberikan gambaran dampak perubahan dari satu peubah terhadap peubah lainnya secara dinamis, perubahan terjadi dengan memberikan guncangan sebesar 1 standar deviasi (innovations) pada salah satu peubah endogen. Respon yang diterima BOPO dari guncangan BOPO itu sendiri memberikan dampak perubahan sangat besar dan fluktuasi BOPO dominan dipengaruhi oleh guncangan BOPO itu sendiri. Respon variabel lain dari guncangan variabel dirinya sendiri yang berdampak perubahan besar dengan guncangan sebesar 1 standar deviasi terjadi juga pada variabel DPK, GAST dan NPF. Hal ini menandakan perkembangan perbankan syariah kedepan sangat dipengaruh oleh variabel BOPO, DPK, GAST dan NPF dalam perkembangannya. Sedangkan variabel PKJ dan PYD mengalami perubahan dengan adanya guncangan variabel DPK dan BOPO.

Perkembangan perbankan syariah selanjutnya akan terus tumbuh, berdasarkan hasil penelitian dalam jangka panjang secara signifikan dipengaruhi oleh pembiayaan yang diberikan di sektor UKM yang merupakan bentuk perhatian dari perbankan syariah dalam menggerakkan sektor riil. Upaya meningkatkan kapasitas pembiayaan perbankan syariah melalui dana pihak ketiga (DPK) sebagai sumber pendanaan untuk meningkatkan kapasitas pembiayaan. Adanya program pemerintah tentang pencanangan Gerakan Ekonomi Syariah (GRES) akan memperkuat perkembangan perbankan syariah dari sisi sistem dan regulasi, salah satu kebijakan yang berkomitmen mendukung perkembangan syariah adalah sistem pengelolaan dana haji harus menggunakan prinsip-prinsip syariah (pasal 22 ayat 1 UU Nomor 13 tahun 2008). Rasio biaya operasional terhadap pendapatan operasional (BOPO) sebagai rasio efisiensi digunakan untuk mengukur kemampuan manajemen bank dalam mengendalikan biaya operasional terhadap pendapatan operasional, semakin kecil rasio ini berarti semakin efisien biaya operasional. Untuk meningkatkan kinerja efisiensi, perbankan syariah dapat memanfaatkan potensi dana pihak ketiga digunakan secara tepat yang mendukung terwujudnya kinerja efisiensi optimal yang dimanfaatkan untuk kegiatan pembiayaan pada sektor riil. Adanya peraturan dan kebijakan pemerintah (office channeling) atas perbankan syariah memberi dampak yang lebih besar bagi perkembangan perbankan syariah. Perkembangan perbankan syariah sangat dipengaruhi dengan adanya peranan bank umum konvensional yang melaksanakan kegiatan usaha berdasarkan prinsip syariah.

\section{SIMPULAN DAN SARAN}

Hasil penelitian menerangkan bahwa pengaruh variabel-variabel perkembangan perbankan syariah dipengaruhi data satu periode sebelumnya (lag 1), kointegrasi yang terbentuk ada 6 persamaan dengan variabel PYD berpengaruh signifikan pada taraf nyata $5 \%$ dalam jangka panjang, sedangkan dalam jangka pendek variabel-variabel lainnya tidak

Uding Sastrawan, M. Syamsun, M. Najib 
berpengaruh signifikan. Secara keseluruhan terdapat 3 hubungan yang diperoleh dari hasil uji Granger causality, variabel yang memiliki hubungan dua arah, satu arah dan tidak terjadi hubungan diantaranya.

Hasil analisis respon dinamis terhadap guncangan variabel perkembangan perbankan syariah sebesar 1 standar deviasi terhadap variabel dirinya sendiri memberikan dampak perubahan terbesar terjadi pada BOPO, DPK, GAST dan NPF, sedangkan variabel PKJ dan PYD mengalami perubahan dengan adanya guncangan variabel DPK dan BOPO. Adapun fluktuasi BOPO, DPK, GAST dan NPF dominan dipengaruhi oleh guncangan variabel dirinya sendiri. Perkembangan perbankan syariah dengan adannya kebijakan office channeling memberikan perbedaan yang signifikan dibandingkan sebelum office channeling. Variabel yang berpengaruh nyata adalah PKJ, DPK, PYD, BOPO dan NPF, sedangkan GAST tidak berpengaruh nyata.

Perbankan syariah dapat terus berkembang dalam jangka panjang dengan meningkatkan pembiayaan yang diberikan di sektor real seperti UKM. Namun, pengawasan dalam sistem pemberian pembiayaan terutama yang bersifat ekspansif konsisten dijalankan. Selain itu, dalam kondisi jangka pendek pengaruh variabel perkembangan perbankan syariah secara umum belum memberikan pengaruh yang signifikan, oleh karena itu perlu ditingkatkan pencapaian hasil dari setiap variabelnya.

\section{DAFTAR PUSTAKA}

Ascarya. 2009. "Toward Optimum Synergy of Monetary Policy in Dual Financial/Banking System". Journal of Indonesia Economy and Business, Vol.24 No.1

Enders W. 1995. Applied Econometric Time Series. New York (US): J Wiley

Newbold P, Carison WL, Thorne B. 2007. Statistics for Business and Economics, $6^{\text {th }}$ ed. Pearson Prentice Hall. [Internet]. $\quad$ [diunduh $2013 \quad$ Agustus 24]. http://www.wps.prenhall.com/bp_newbold_statbuse_6/53/13701/3507537.cw/index.html_chap11.ppt.

Perwataatmaja, Karnaen. 2002. Prospek Bank Islam sebagai Alternatif Pemecahan Problema Lembaga Keuangan Konvensional. Dalam : Ashari Akmal Tarigan. Ekonomi dan Bank Syariah pada Millenium Ketiga. Medan (ID): IAIN Pr.

Rohaya H. 2008. Perkembangan Skala Usaha Perbankan Syariah di Indonesia Pra dan Pasca Kebijakan Office Channeling. Jurnal Ekonomi Islam La Riba Vol. II No. 2

Sutaryo. 2004. Pengaruh Karakterstik Inovasi terhadap Adopsi Teknologi Internet oleh UKM. Jurnal Ekonomi dan Keuangan. Vol. 2 No. 2 